\title{
PERAN PERSEPSI HARGA DALAM MEMEDIASI BRAND IMAGE TERHADAP NIAT BELI KONSUMEN
}

\author{
Putu Ema Arini ${ }^{1}$ \\ Ida Bagus Sudiksa ${ }^{2}$
}

\author{
${ }^{1,2}$ Fakultas Ekonomi dan Bisnis Universitas Udayana, Bali, Indonesia \\ 1e-mail: emaarinii@gmail.com
}

\begin{abstract}
ABSTRAK
Meningkatnya budaya niat, terutama di bidang kuliner makanan yang menyajikan berbagai jenis roti, kue seiring dengan kebutuhan dan berkembangnya gaya hidup masyarakat. Tujuan penelitian ini adalah untuk menganalisis peran persepsi harga dalam memediasi brand image terhadap niat beli konsumen pada Pie Susu Asli Enaaak. Penelitian ini dilakukan di Kota Denpasar dengan teknik analisis data Path Analisis. Ukuran sampel yang didapat dengan menggunakan metode purposive sampling sebanyak 110 responden. Berdasarkan hasil analisis dapat dikemukakan bahwa brand image berpengaruh positif dan signifikan terhadap niat beli konsumen pada Pie Susu Asli Enaaak di Kota Denpasar. Brand image berpengaruh positif dan signifikan terhadap persepsi harga konsumen pada Pie Susu Asli Enaaak di Kota Denpasar. Persepsi harga berpengaruh positif dan signifikan terhadap niat beli konsumen pada Pie Susu Asli Enaaak di Kota Denpasar. Persepsi harga memediasi pengaruh positif brand image terhadap niat beli konsumen pada Pie Susu Asli Enaaak di Kota Denpasar.
\end{abstract}

Kata kunci: brand image, persepsi harga, niat beli

\begin{abstract}
Increased cultural intentions, especially in the field of food culinary that presents various types of bread, cakes along with the needs and development of people's lifestyles. The purpose of this study is to analyze the role of price perception in mediating brand image on consumer purchase intention on Pie Susu Asli Enaaak This research was conducted in Denpasar City with data analysis technique of Path Analysis. Sample size obtained by using purposive sampling method counted 110 respondents. Based on the results of the analysis can be stated that the brand image has a positive and significant impact on consumer purchase intention on Pie Susu Asli Enaaak in Denpasar City. Brand image has a positive and significant influence on consumer price perception on Pie Susu Asli Enaaak in Denpasar City. Price perceptions have a positive and significant impact on consumer purchase intention on Pie Susu Asli Enaaak in Denpasar City. Price perception mediates the positive effect of brand image on consumer purchase intention on Pie Susu Asli Enaaak in Denpasar City.
\end{abstract}

Keywords: brand image, price perception, purchase intention 


\section{PENDAHULUAN}

Kondisi persaingan pasar saat ini, membuat konsumen selektif dalam melakukan pembelian dan semakin kritis dalam perilaku pembeliannya (Saadia, 2013). Salah satu jenis produk yang diminati masyarakat adalah produk makanan yang menyajikan berbagai jenis roti, kue dll. Masyarakat modern merupakan masyarakat yang memerlukan kebutuhan serba instan. Seiring dengan aktivitas yang semakin sibuk dan kesadaran masyarakat akan pentingnya makanan bergizi, maka kue merupakan salah satu pilihan makanan alternatif di segala kondisi waktu dan makan.

Pelaku usaha industri kue di Indonesia umumnya didominasi oleh kalangan pengusaha berskala mikro, kecil dan menengah (Pangastuti dan Purnami, 2015). Usaha mikro ini semakin hari semakin menunjukkan peningkatan, berdasarkan data Asosiasi Pengusaha Bakery Indonesia (Apebi) menjelaskan pasar roti dan kue di Indonesia terus meningkat. Melihat hal ini, masing-masing perusahaan berlombalomba untuk mengatur strategi pemasaran yang tepat untuk dapat menarik perhatian konsumen dan mendapatkan pelanggan sebanyak mungkin strategi itu dituangkan dalam sebuah kerangka pemasaran perusahaan tersebut dalam sebuah bentuk bauran pemasaran untuk mempengaruhi keputusan pembelian melalui persepsi harga dan brand image perusahaan (Thiripura sundari, 2011).

Keputusan yang dibuat konsumen terhadap suatu produk atau jasa adalah suatu proses penilaian dan penerimaan dari informasi merek, pertimbangan bagaimana merek-merek yang lain dapat memenuhi kebutuhan konsumen dan pada akhirnya memutuskasn merek yang dipilih (Eko dan Budi, 2013). Keinginan untuk membeli pada konsumen akan timbul ketika mereka merasa tertarik, ingin 
menggunakan, dan memiliki produk yang dilihatnya. Menurut Kotler (2007:162) keputusan pembelian adalah proses pengintegrasian yang mengkombinasikan pengetahuan untuk mengevaluasi dua atau lebih perilaku alternatif dan memilih salah satu diantaranya. Jika konsumen tidak memiliki pengalaman dengan suatu produk, mereka cenderung untuk mempercayai merek yang disukai atau yang terkenal (Schiffman dan Kanuk, 2010:173).

Pada umumnya, keputusan pembelian konsumen adalah membeli merek yang paling disukai (Kotler dan Amstrsong, 2008:181). Alasan inilah yang mendorong perusahaan untuk memperkuat posisi mereknya agar tercipta brand image yang positif dan menancap kuat di benak konsumen karena melalui brand image (citra merek), konsumen mampu mengenali sebuah produk, mengevaluasi kualitas, mengurangi resiko pembelian, dan memperoleh pengalaman dan kepuasan dari diferensiasi produk tertentu (Julina dan Desrir, 2014). Keputusan pembelian pada Pie Susu Asli Enaaak masih rendah, ini dibuktikan dengan penjualan Pie Susu Asli yang mengalami naik turun atau fluktuasi.

Andrie dan Harold (2013) menyatakan salah satu pertimbangan keputusan pembelian adalah merek, dimana merek sangat berpengaruh bagi niat beli konsumen. Sebuah merek yang terkenal memiliki keistimewaan tersendiri bagi konsumen. Melihat fakta yang terjadi, konsumen banyak melakukan keputusan pembelian jika produk tersebut memiliki merek yang terkenal dibandingkan dengan produk yang mempunyai merek standar.

Kotler (2007: 460) menyatakan merek adalah suatu nama, istilah, tanda, lambang, rancangan atau kombinasi dari hal-hal tersebut yang dimaksud untuk 
mengidentifikasi barang atau jasa dari seseorang atau sekelompok pejual dan untuk membedakannya dari produk pesaing. Merek dapat digunakan untuk mempromosikan hasil produk suatu perusahaan, selain itu merek juga bisa mencerminkan atas mutu dan kualitas produknya (Parisa, 2014). Sedangkan citra merek merupakan keyakinan atas penilaian dari merek. Konsumen yang menilai positif citra merek tersebut, akan lebih mungkin untuk melakukan keputusan pembelian (Rahmawati et al., 2007). Produk-produk produsen yang sudah ada di pasaran saat ini dituntut untuk lebih kreatif dan memperbanyak variasi serta inovasi produknya sesuai kebutuhan konsumen dan pasar, sedangkan citra merek (brand image) suatu produk merupakan representasi dari keseluruhan persepsi terhadap merek dan dibentuk dari informasi dan pengalaman masa lalu terhadap merek itu. Pengaruh citra merek suatu produk berhubungan dengan keyakinan dan preferensi konsumen terhadap suatu merek produk. Konsumen yang memiliki citra positif terhadap suatu merek tertentu, akan lebih memungkinkan konsumen tersebut untuk melakukan pembelian ulang dari produk-produk yang dihasilkan dari merek perusahaan tersebut (Sreejesh, 2015).

Beberapa penelitian menyebutkan citra merek atau brand image memiliki pengaruh terhadap keputusan pembelian konsumen. Penelitian (Deviana, 2014) menyatakan citra merek atau brand image memiliki pengaruh positif terhadap niat beli konsumen. Penelitian Harmancioglu et al. (2009) membuktikan bahwa brand image memiliki pengaruh positif terhadap keputusan pembelian konsumen. Johan (2010) menyatakan hal yang sama dimana brand image memiliki pengaruh positif terhadap niat beli konsumen. Kevin (2014) menyatakan bahwa brand image tidak 
memiliki pengaruh positif terhadap niat beli konsumen. Zohreh dan Arman (2013) menyatakan brand image tidak memiliki pengaruh terhadap niat beli konsumen. Ayu dan Kerti (2014) menyatakan bagi konsumen brand image memiliki pengaruh positif untuk meningkatkan niat beli. Kambiz and Mohammad (2012) menyatakan bahwa citra merek atau brand image memiliki pengaruh positif terhadap niat beli konsumen.

Pangastuti dan Purnami (2015) menyatakan selain brand image atau citra merek, persepsi harga juga merupakan salah satu faktor yang mempengaruhi niat pembelian konsumen. Kotler dan Keller (2009:117) menjelaskan persepsi harga merupakan suatu proses dimana seorang menyeleksi, mengorganisasikan, menginterpretasikan stimuli dalam suatu gambaran yang berarti menyeluruh. Persepsi harga merupakan unsur bauran pemasaran yang fleksibel, artinya dapat berubah dengan cepat sesuai dengan keadaan. Persepsi juga berpengaruh kuat pada konsumen secara umum, persepsi harga merupakan salah satu pertimbangan penting dalam proses keputusan pembelian, dan kebanyakan konsumen mengevaluasi nilai (kombinasi antara harga dan kualitas) dalam keputusan pembelian. Penetapan harga oleh penjual akan berpengaruh terhadap perilaku pembelian konsumen, sebab harga yang dapat dijangkau oleh konsumen akan cenderung membuat konsumen melakukan pembelian terhadap produk tersebut (Kotler dan Armstrong, 2012:263).

Beberapa penelitian menyebutkan persepsi harga memiliki pengaruh terhadap keputusan pembelian konsumen. Penelitian Eko dan Budi (2013) menyatakan persepsi harga memiliki pengaruh positif terhadap keputusan pembelian konsumen. 
Kevin (2014) menyebutkan bahwa persepsi harga sebagai salah satu faktor yang mempengaruhi niat beli konsumen. Hal yang sama dinyatakan oleh Johan (2010) variabel persepsi harga memiliki pengaruh positif terhadap niat beli konsumen. Ayu dan Kerti (2014) menyatakan persepsi harga tidak memiliki pengaruh positif terhadap niat beli konsumen. Sreejesh (2015) menyatakan hal yang sama persepsi harga tidak berpengaruh positif terhadap niat beli konsumen. Kambiz and Mohammad (2012) persepsi harga memiliki pengaruh positif dalam meningkatkan niat beli konsumen. Jamaliah et al. (2013) menyatakan persepsi harga secara positif berpengaruh terhadap niat beli konsumen.

Tanpa adanya persepsi harga dan citra merek yang kuat dan positif, sangatlah sulit bagi perusahaan untuk menarik pelanggan baru dan mempertahankan niat beli konsumen (Joshi, 2012). Citra merek memiliki arti segala persepsi konsumen tentang merek dan bagaimana cara memandangnya, bisa tidak serupa dengan identitas merek (Hossain, 2007). Keyakinan dan preferensi konsumen terhadap persepsi harga suatu produk akan meningkatkan citra merek produk dari perusahaan. Zohreh and Arman (2013) menyatakan bahwa konsumen dengan keyakinan serta preferensi konsumen terhadap persepsi harga memiliki hubungan positif dengan citra merk sehingga lebih memungkinkan untuk meningkatkan niat beli konsumen Kuenzel dan Halliday (2008:293).

Beberapa penelitian menyatakan citra merek berpengaruh positif dengan niat beli konsumen melalui mediasi persepsi harga. Parisa (2014) menyatakan dalam penelitiannya persepsi harga mampu memediasi pengaruh positif citra merek terhadap niat beli konsumen. Kuang et al. (2011) membuktikan dalam 
penelitiannya citra merek berpengaruh positif dengan niat beli konsumen melalui mediasi persepsi harga. Yungki (2010) dalam penelitiannya membuktikan persepsi harga mampu memediasi pengaruh positif citra merek terhadap niat beli konsumen. Kevin (2014) menemukan dalam penelitiannya persepsi harga mampu memediasi pengaruh citra merek terhadap niat beli konsumen. Ria dan Gatot (2014) membuktikan terdapat peran mediasi persepsi harga dalam menciptakan pengaruh positif citra merek terhadap niat beli konsumen.

Pie Susu Asli Enaaak merupakan salah satu perusahaan kue yang memproduksi pie susu di Daerah Denpasar Provinsi Bali yang menyediakan berbagai macam rasa Pie Susu. Pie Susu Asli Enaaak merupakan pie susu yang pertama kali di Bali sehingga pie susu bisa menjadi oleh-oleh khas Bali. Perusahaan yang memproduksi pie susu ini semakin banyak sehingga menimbulkan persaingan yang semakin ketat.

Tuntutan untuk memenangkan persaingan Pie Susu Asli Enaaak harus mampu mempertahankan citra merek dan persepsi harga kepada konsumen. Niat beli konsumen sangat penting artinya bagi perusahaan yang menjaga kelangsungan usahanya maupun kelangsungan kegiatan usahanya. Niat beli konsumen akan dapat dipertahankan bila konsumen merasa senang dan puas dengan citra merek dan persepsi harga suatu produk, sehingga mempunyai antusiasme untuk memperkenalkannya kepada siapapun yang mereka kenal.

Theory of Trying adalah teori yang dikembangkan oleh Bagozzi dan Warshaw dalam usaha menjelaskan ketidakpastian konsumen ketika pencapaian dari tujuan konsumsi tidak sepenuhnya berada dalam kontrol kemauan seseorang. Menurut 
Agarwal dan Sinha (2003:112) disebutkan bahwa Theory of Trying dimaksudkan untuk menjelaskan hubungan antara niat dan perilaku dengan menyelidiki orangorang yang berupaya keras untuk melaksanakan perilaku tersebut. Hal ini berarti apabila seorang individu mencoba untuk mencapai suatu tujuan, maka individu tersebut akan melihatnya sebagai beban potensial yang hanya memiliki dua kemungkinan yaitu kemungkinan mencoba tetapi tidak berhasil dan yang kedua adalah gagal untuk mencoba.

Suprapti (2010:68) persepsi merupakan sebuah proses yang harus dilalui oleh konsumen untuk memilih, mengorganisasi, menginterpretasi stimuli ke dalam sebuah gambaran yang bersifat koheren. Menurut Mangkunegara (2011:21) "Perilaku konsumen didefinisikan sebagai tindakan individu yang secara langsung terlibat dalam usaha memperoleh dan menggunakan barang-barang serta jasa ekonomis termasuk proses pengambilan keputusan yang mendahului dan menentukan tindakan-tindakan tersebut". Perilaku konsumen (consumer behavior) adalah proses yang terjadi pada konsumen ketika memutuskan untuk membeli, apa yang dibeli, dimana, kapan, dan bagaimana membelinya. Sehingga, dapat disimpulkan bahwasanya perilaku konsumen merupakan suatu proses yang terusmenerus (berkesinambungan).

Berdasarkan beberapa pendapat tersebut dapat disimpulkan bahwa perilaku konsumen adalah semua kegiatan, tindakan serta proses psikologis yang mendorong tindakan tersebut pada saat sebelum membeli, ketika membeli, menggunakan produk dan jasa setelah melakukan hal-hal tersebut diatas atau kegiatan mengevaluasi. 
Pavlou (2003) dalam niat untuk bertransaksi, dapat didefinisikan sebagai niat konsumen untuk terlibat dalam berbagai hubungan pertukaran online dengan penjual pada suatu web, seperti berbagi informasi bisnis, menjaga hubungan bisnis, dan melakukan transaksi bisnis. Didalam konsep B2C e-commerce, konsumen memerlukan niat untuk menentukan penjual online mana yang dipilih, website untuk mendapatkan dan memberikan informasi dan kemudian menyelesaikan transaksi dengan membeli produk atau jasa tersebut. Pavlou (2003) juga menjelaskan bahwa dalam bertransaksi online terdapat dimensi yang unik, dimana konsumen harus secara aktif terlibat dalam suatu penggunaan teknologi dan adanya interaksi dengan penjual online, pemisahan antara konsumen dan penjual online melalui webstore juga meningkatkan kekhawatiran yang timbul dari suatu produk yang identitasnya tidak pasti, dan ada kekhawatiran mengenai kelayakan internet itu sendiri dan infrastruktur terkait dimana hanya website sebagai media untuk berinteraksi dengan konsumen (misalnya, suatu infrastruktur yang lemah menimbulkan ketakutan bahwa pihak ketiga atau hacker dapat mengancam privasi dan informasi keuangan konsumen terkait).

Perilaku niat didefinisikan Mowen and Minor (2007) sebagai keinginan konsumen untuk berperilaku menurut cara tertentu dalam rangka memiliki, membuang, dan menggunakan produk atau jasa. Jadi konsumen dapat membentuk keinginan untuk mencari informasi, memberitahukan orang lain tentang pengalamannya dengan sebuah produk, membeli sebuah produk atau jasa tertentu, atau membuang produk dengan cara tertentu. 
Pengambilan keputusan konsumen akan berbeda-beda, tergantung pada jenis keputusan pembelian. Pembelian yang rumit dan mahal akan melibatkan lebih banyak pertimbangan yang diperlukan oleh pembelian. Menurut Assael (Kotler, 2007:221), terdapat empat jenis perilaku pembelian konsumen berdasarkan tingkat keterlibatan pembeli dan tingkat diferensiasi mereka, yaitu perilaku pembelian yang rumit : konsumen terlibat dalam perilaku pembelian yang rumit bila mereka sangat terlibat dalam pembelian dan sadar akan adanya perbedaan yang signifikan diantara berbagai merek, dimana ini terjadi bila produknya mahal, jarang dibeli, berisiko dan sangat mengekspresikan kepribadian. Perilaku pembelian pengurang ketidaknyamanan/ Disonasi : pada perilaku pembelian ini konsumen menjadi sangat terlibat dalam sebuah pembelian, namun melihat sedikit perbedaan diantara berbagai merek. Keterlibatan yang tinggi disadari adanya kenyataan bahwa pembelian tersebut mahal, jarang dilakukan dan berisiko. Setelah pembelian biasanya akan muncul ketidaksesuaian atau disonasi dari pengamatan terhadap halhal yang mengganggu mengenai produk yang dibeli atau kabar tentang hal-hal yang menyenangkan mengenai produk-produk sejenis lainnya. Perilaku pembelian karena kebiasaan : perilaku pembelian ini terjadi bila terdapat pembelian produk dengan tingkat keterlibatan konsumen yang rendah, serta adanya perbedaan merek yang signifikan. Konsumen akan melakukan pembelian dengan mengambil merek tertentu secara berulang-ulang dimana hal tersebut dilakukan lebih karena kebiasaan daripada adanya kesetiaan terhadap suatu merek tertentu. Perilaku pembelian yang mencari variasi : pada perilaku ini situasi pembelian ditandai oleh adanya keterlibatan yang rendah oleh konsumen, namun terdapat perbedaan merek 
yang signifikan. Situasi ini akan menyebabkan konsumen sering melakukan peralihan ke merek lain dan perpindahan merek ini biasanya karena mencari variasi dan bukan karena ketidakpuasan.

Asosiasi Pemasar Amerika (Kotler dan Amstrong, 2012) mendefinisikan merek sebagai nama, istilah, tanda, simbol, atau rancangan, atau kombinasi dari semuanya, yang dimaksudkan untuk mengidentifikasikan barang atau jasa atau kelompok penjualan dan untuk mendiferensiasikannya dari barang dan jasa pesaing. Menurut Undang-Undang Merek No. 15 Tahun 2001 pasal 1 ayat 1 merk merupakan tanda yang berupa gambar, nama, kata, huruf-huruf, angka-angka, susunan warna, atau kombinasi dari unsur-unsur tersebut yang memiliki daya pembeda dan digunakan dalam kegiatan perdagangan barang dan jasa.

Citra merek adalah persepsi konsumen (bagaimana mereka memandangnya) tentang suatu merek, yang tidak serupa dengan indentitas merek (Aaker, 1997), sedangkan menurut Kotler, P. dan Keller (2007:76), citra merek didefenisikan sebagai alasan atau persepsi emosional konsumen untuk mengikatkan diri (memilih) merek tertentu. Citra merek mengandung kepercayaan simbolis dan fungsional akan suatu merek (Ria dan Gatot, 2014), citra merek juga dapat dilihat dari keunikan karateristik yang dimiliki oleh merek (Thiripurasundari and Natarajan, 2011). Rangkuti (2007: 23) menjelaskan merek (brand) yaitu nama, istilah, tanda, simbol, atau desain atau panduan dari hal-hal tersebut yang dimaksudkan untuk memberikan identitas bagi barang atau jasa yang dibuat atau disediakan suatu penjual atau kelompok penjual serta membedakannya dari barang 
atau jasa yang disediakan pesaing. Berikut adalah tabel yang menjelaskan beberapa manfaat merek yang dapat diperoleh pelanggan dan perusahaan.

Menurut Schiffman \& Kanuk (2010) persepsi adalah suatu proses seorang individu dalam menyeleksi, mengorganisasikan, dan menterjamahkan stimulusstimulus informasi yang datang menjadi suatu gambaran yang menyeluruh. Persepsi mempunyai pengaruh yang kuat bagi konsumen. Salah satu faktor yang berpengaruh terhadap konsumen yaitu persepsi akan harga. Menurut Kotler dan Amstrong (2012:89) harga merupakan sejumlah uang yang dibebankan atas suatu produk atau jasa atau jumlah dari nilai yang ditukar konsumen atas manfaatmanfaat karena memiliki atau menggunakan produk atau jasa tersebut.

Tujuan ditetapkan harga sebaiknya bersumber dari dan sesuai dengan tujuan perusahaan dan pemasaran. Tujuan penetepan harga ditetapkan secara jelas karena secara langsung mempengaruhi kebijakan penetepan harga dan cara yang digunakan untuk menetapkan harga.

Citra merek adalah serangkaian kepercayaan yang konsumen pegang atas masing- masing atribut yang istimewa dari sebuah merek (Kotler and Keller, 2007). Oleh karena itu, sikap dan tindakan konsumen terhadap suatu merek sangat ditentukan oleh citra merek tersebut untuk meningkatkan niat beli konsumen.

Beberapa penelitian menyebutkan citra merek atau brand image memiliki pengaruh terhadap keputusan pembelian konsumen. Penelitian (Deviana, 2014) menyatakan citra merek atau brand image memiliki pengaruh positif terhadap niat beli konsumen. Penelitian Harmancioglu et al. (2009) membuktikan bahwa brand image memiliki pengaruh positif terhadap keputusan pembelian konsumen. Johan 
(2010) menyatakan hal yang sama dimana brand image memiliki pengaruh positif terhadap niat beli konsumen. Ayu dan Kerti (2014) menyatakan bagi konsumen brand image memiliki pengaruh positif untuk meningkatkan niat beli. Kambiz and Mohammad (2012) menyatakan bahwa citra merek atau brand image memiliki pengaruh positif terhadap niat beli konsumen. Berdasarkan hasil penelitian tersebut, diajukan hipotesis pertama sebagai berikut.

$\mathrm{H}_{1}$ : citra merek mempengaruhi niat beli konsumen secara positif.

Kotler dan Keller (2007:67) menjelaskan harga adalah satu elemen bauran pemasaran yang menghasilkan pendapatan, elemen lain menghasilkan biaya, dengan adanya persepsi harga yang sesuai dengan keinginan konsumen akan memberikan respon positif terhadap citra merek suatu produk.

Beberapa penelitian menyebutkan citra merek memiliki pengaruh terhadap persepsi harga konsumen. Penelitian (Deviana, 2014) menyatakan citra merek atau brand image memiliki pengaruh positif terhadap persepsi harga konsumen. Penelitian Harmancioglu et al. (2009) membuktikan bahwa brand image memiliki pengaruh positif terhadap persepsi harga konsumen. Johan (2010) menyatakan hal yang sama dimana brand image memiliki pengaruh positif terhadap niat beli konsumen. Penelitian Eko dan Budi (2013) menyatakan citra merek memiliki pengaruh positif terhadap persepsi harga konsumen. Kevin (2014) menyebutkan bahwa brand image sebagai salah satu faktor yang mempengaruhi persepsi harga konsumen. Berdasarkan pemahaman tersebut dapat dirumuskan hipotesis kedua sebagai berikut.

$\mathrm{H}_{2}$ : citra merek mempengaruhi persepsi harga konsumen secara positif. 
Penilaian yang obyektif terhadap harga menciptakan persepsi harga konsumen. Shiffman dan Kanuk (2010) dalam mengindikasikan bagaimana konsumen mempersepsikan harga, baik itu tinggi atau rendah, akan memiliki pengaruh yang kuat terhadap intensitas pembelian konsumen. Selain itu, literatur pemasaran umum mendukung gagasan bahwa faktor-faktor harga mempengaruhi persepsi harga pelanggan, yang pada gilirannya berkontribusi terhadap intensitas pembelian konsumen.

Beberapa penelitian menyebutkan persepsi harga memiliki pengaruh terhadap keputusan pembelian konsumen. Penelitian Eko dan Budi (2013) menyatakan persepsi harga memiliki pengaruh positif terhadap keputusan pembelian konsumen. Kevin (2014) menyebutkan bahwa persepsi harga sebagai salah satu faktor yang mempengaruhi niat beli konsumen. Hal yang sama dinyatakan oleh Johan (2010) variabel persepsi harga memiliki pengaruh positif terhadap niat beli konsumen. Kambiz and Mohammad (2012) persepsi harga memiliki pengaruh positif dalam meningkatkan niat beli konsumen. Jamaliah et al. (2013) menyatakan persepsi harga secara positif berpengaruh terhadap niat beli konsumen. Berdasarkan pemahaman tersebut dapat dirumuskan hipotesis ketiga sebagai berikut.

$\mathrm{H}_{3}$ : persepsi harga mempengaruhi niat beli konsumen secara positif.

Niat beli konsumen sangat dipengaruhi secara positif dan signifikan oleh persepsi harga dan citra merek suatu produk (Shiffman dan Kanuk, 2010). Kotler dan Keller (2007:72) penilaian yang obyektif terhadap persepsi harga menciptakan citra merek yang positif dimata konsumen, baik itu tinggi atau rendah, akan memiliki pengaruh yang kuat terhadap intensitas pembelian konsumen. 
Beberapa penelitian menyatakan citra merek berpengaruh positif dengan niat beli konsumen melalui mediasi persepsi harga. Parisa (2014) menyatakan dalam penelitiannya persepsi harga mampu memediasi pengaruh positif citra merek terhadap niat beli konsumen. Kuang et al. (2011) membuktikan dalam penelitiannya citra merek berpengaruh positif dengan niat beli konsumen melalui mediasi persepsi harga. Yungki (2010) dalam penelitiannya membuktikan persepsi harga mampu memediasi pengaruh positif citra merek terhadap niat beli konsumen. Kevin (2014) menemukan dalam penelitiannya persepsi harga mampu memediasi pengaruh citra merek terhadap niat beli konsumen. Ria dan Gatot (2014) membuktikan terdapat peran mediasi persepsi harga dalam menciptakan pengaruh positif citra merek terhadap niat beli konsumen. Berdasarkan hasil penelitian tersebut, diajukan hipotesis ke empat sebagai berikut.

$\mathrm{H}_{4}$ : persepsi harga memediasi pengaruh citra merek terhadap niat beli konsumen secara positif.

\section{METODOLOGI PENELITIAN}

Penelitian dilakukan di Pie Susu Asli Enaaak di Kota Denpasar. Lokasi ini dipilih karena Pie Susu Asli Enaaak merupakan salah satu pusat penjualan Kue Pie Susu di Kota Denpasar dan Kota Denpasar merupakan pusat perekonomian di Bali yang memiliki tingkat pertumbuhan di sektor ekonomi sangat cepat serta jumlah penduduk yang padat dan populasi yang cukup tinggi. Selain itu secara teknis, Kota Denpasar memenuhi kategori yang dinilai efektif dan efisien dalam menyelenggarakan penelitian yang relevan, mengingat dengan tingkat kepadatan penduduk di Kota Denpasar sangat memungkinkan perusahaan menjual produknya untuk mendapatkan keuntungan. 
Variabel endogen dalam penelitian ini adalah niat beli konsumen (X1). Variabel eksogen dalam penelitian ini adalah citra merek (Y). Variabel yang menjadi mediasi dalam penelitian ini adalah persepsi harga (M).

Populasi dalam penelitian ini adalah seluruh konsumen yang memiliki niat beli pada produk Pie Susu Asli Enaaak di Kota Denpasar, yang tidak diketahui jumlahnya. Dalam penelitian ini sampel diambil dengan teknik non probability sampling. Yaitu teknik yang tidak memberi peluang atau kesempatan sama bagi setiap unsur atau anggota populasi untuk dipilih menjadi sampel. Teknik pemilihan sampel menggunakan teknik purposive sampling, yaitu teknik penentuan sampel berdasarkan pertimbangan maupun syarat - syarat tertentu.

Teknik analisis data yang digunakan dalam penelitian ini adalah teknik analisis jalur (path analysis). Analisis jalur merupakan perluasan dari analisis regresi linier berganda, untuk menaksir hubungan kausalitas antar variabel yang berjenjangberdasarkan teori (Utama, 2016:135).

\section{HASIL PENELITIAN DAN PEMBAHASAN}

Karakteristik responden dapat dilihat berdasarkan pengelompokkan jenis kelamin, jenis kelamin perempuan mendominasi dalam penelitian ini dengan persentase sebesar 70,9 persen, hal ini disebabkan karena kebanyakan perempuan yang menyukai produk makanan Pie Susu Asli Enaaak sebagai jajanan, oleh-oleh maupun untuk hari raya tertentu sehingga selalu memiliki keinginan untuk membelinya.

Karakteristik responden berdasarkan umur responden di dominasi pada usia 17-35 tahun dengan persentase sebesar 61,9 persen. Persentase terkecil yaitu 6,3 persen dengan jumlah responden sebanyak 7 orang yang berumur $>55$ tahun. Hal 
ini berarti bahwa, masyarakat Kota Denpasar yang yang menyukai produk makanan Pie Susu Asli Enaaak di Kota Denpasar rata-rata berumur 17-35 tahun di mana rentang usia ini termasuk rentak usia yang produktif selalu aktif yang ingin selalu mencoba jenis makanan baru dan enak.

Karakteristik responden dapat dilihat berdasarkan pengelompokkan pendidikan terakhir, pendidikan terakhir S1 mendominasi dalam penelitian ini dengan jumlah responden sebanyak 52 orang 47,3 persen dan persentase terkecil yaitu 9,1 persen dengan jumlah responden sebanyak 10 orang yang berpendidikan SLTP. Hal ini dikarenakan dalam kategori pendidikan, ini dianggap sudah memiliki penghasilan sendiri yang cukup untuk bergaya up to date untuk melakukan pembelian produk makanan Pie Susu Asli Enaaak di Kota Denpasar.

Karakteristik responden dapat dilihat berdasarkan penghasilan di dominasi dari masyarakat yang berpenghasilan rata-rata Rp. >Rp.4.000.000-s/d Rp. 5.000.000,- dengan jumlah responden sebanyak 62 orang atau 56,4 persen. Masyarakat yang berpenghasilan Rp. 4.000.000,- memiliki persentase terendah yaitu 6,3 persen. Hal ini dapat dilihat masyarakat yang membeli produk makanan Pie Susu Asli Enaaak di Kota Denpasar termasuk dalam kategori masyarakat menengah atas yang disebabkan harga yang lumayan mahal dan rasa yang sangat enak.

Dari model jalur yang dibentuk, terdapat dua persamaan struktural atau sistem persamaan simultan. Dari hasil pengolahan data dengan SPSS, model persamaan struktural atau sistem persamaan simultan untuk struktur pertama dan struktur kedua, menunjukkan hasil seperti pada Tabel 1. dan Tabel 2. 
Tabel 1.

Rekapitulasi Hasil Regresi Struktur 1

\begin{tabular}{llccc}
\hline & Model & $\begin{array}{c}\text { Standardized } \\
\text { Coefficients } \\
\text { Beta }\end{array}$ & $\mathbf{T}$ & Sig. \\
\hline (Constant) & & 3.511 & 5.047 & 0.000 \\
Brand image & $: 0,579$ & 0.425 & 12.188 & 0.000 \\
$\mathrm{R}^{2}$ & & & \\
F Statistik & $: 148,537$ & & & \\
Sig.F & $: 0,000$ & & & \\
Sumber: Data diolah, 2018 & &
\end{tabular}

Berdasarkan laporan pada Tabel 1 maka persamaan strukturalnya adalah sebagai berikut:

$$
\begin{aligned}
& M=0.425 X \\
& \mathrm{Se}=0.000 \\
& \mathrm{t}=12.188 \\
& \text { Sig. } \mathrm{t}=0.000 \\
& \text { F Statistik }=148.537 \\
& \text { Sig. } \mathrm{F}=0.000 \\
& \mathrm{R}^{2}=0.579
\end{aligned}
$$

Berdasarkan Tabel 1. diperoleh nilai standar eror sebagai berikut:

$$
\mathrm{Pe}_{\mathrm{i}}=\sqrt{1-R_{1}^{2}}
$$

$$
\mathrm{Pe}_{1}=\sqrt{\left(1-R_{1}^{2}\right)}=\sqrt{1-0,579}=0,648
$$

Tabel 1 menjelaskan hasil pengujian pengaruh variabel brand image (X) terhadap persepsi harga (M) dijelaskan bahwa brand image berpengaruh positif signifikan terhadap persepsi harga dengan nilai standardized coefficients beta sebesar 0,425 dan nilai sig t sebesar $0,000<0,05$, oleh karena nilai standardized coefficients beta sebesar 0,425 dengan nilai sig $\mathrm{t}=0,000$ maka $\mathrm{H}_{0}$ diterima. Hal ini berarti variabel brand image berpengaruh positif dan signifikan secara parsial terhadap persepsi harga konsumen pada Pie Susu Asli Enaaak. 
Tabel 2.

Rekapitulasi Hasil Regresi Struktur 2

Standardized Coefficients

\begin{tabular}{lccc}
\multicolumn{1}{c}{ Model } & Beta & T & Sig. \\
\hline (Constant) & 0.580 & 0.567 & 0.572 \\
Brand image & 0.327 & 4.607 & 0.000 \\
Persepsi harga & 0.383 & 3.013 & 0.003 \\
$\mathrm{R}^{2}: 0,533$ & & & \\
F Statistik $\quad: 61,078$ & & & \\
Sig.F $\quad: 0,000$ & & & \\
\hline \multicolumn{2}{l}{ Sumber: Data diolah, 2018}
\end{tabular}

Berdasarkan laporan pada Tabel 2., maka persamaan strukturalnya adalah sebagai berikut:

$$
\begin{aligned}
& \mathrm{Y}=0.327 \mathrm{X}+0.383 \mathrm{M} \\
& \mathrm{Se}=0.000 \\
& \mathrm{t}=4.607 \text { (brand image) dan } 3.013 \text { (persepsi harga) }
\end{aligned}
$$

Sig. $\mathrm{t}=0.000$

F Statistik $=61.078$

Sig. $F=0.000$

$$
\mathrm{R}^{2}=0.533
$$

Berdasarkan Tabel 2. Diperoleh nilai standar eror sebagai berikut :

$$
\begin{array}{r}
\mathrm{Pe}_{\mathrm{i}}=\sqrt{1-R_{1}^{2}} \ldots \ldots \ldots \ldots \ldots \ldots \ldots \ldots \\
\mathrm{Pe}_{2}=\sqrt{\left(1-R_{1}^{2}\right)}=\sqrt{1-0,533}=0,683
\end{array}
$$

Tabel 2 menjelaskan hasil pengujian pengaruh variabel brand image (X) terhadap niat beli konsumen (Y) dijelaskan bahwa brand image berpengaruh positif signifikan terhadap niat beli konsumen dengan nilai standardized coefficients beta sebesar 0,327 dan nilai sig t sebesar $0,000<0,05$, oleh karena nilai standardized coefficients beta sebesar 0,327 dengan nilai sig $\mathrm{t}=0,000$ maka $\mathrm{H}_{0}$ diterima. Hal ini 
berarti variabel brand image berpengaruh positif dan signifikan secara parsial terhadap niat beli konsumen pada Pie Susu Asli Enaaak di Kota Denpasar.

Hasil pengujian pengaruh variabel persepsi harga $(\mathrm{M})$ terhadap niat beli konsumen (Y) dijelaskan bahwa persepsi harga berpengaruh positif signifikan terhadap niat beli konsumen dengan nilai standardized coefficients beta sebesar 0,383 dan nilai sig t sebesar $0,003<0,05$, oleh karena nilai standardized coefficients beta sebesar 0,383 dengan nilai sig $\mathrm{t}=0,003$ maka $\mathrm{H}_{0}$ diterima. Hal ini berarti variabel persepsi harga berpengaruh positif dan signifikan secara parsial terhadap niat beli konsumen pada Pie Susu Asli Enaaak di Kota Denpasar.

Berdasarkan hasil dari koefisien jalur pada hipotesis penelitian, maka dapat digambarkan hubungan kausal antar variabel persepsi harga memediasi pengaruh brand image terhadap niat beli konsumen pada Pie Susu Asli Enaaak di Kota Denpasar. Perhitungan pengaruh antar variabel dirangkum dalam Tabel 3

Tabel 3.

Pengaruh langsung dan pengaruh tidak langsung serta pengaruh total brand image $(\mathrm{X})$ terhadap niat beli konsumen $(\mathrm{Y})$ dengan mediasi persepsi harga

(M)

\begin{tabular}{llccc}
\hline Pengaruh Variabel & $\begin{array}{c}\text { Pengaruh } \\
\text { Langsung }\end{array}$ & $\begin{array}{c}\text { Pengaruh Tidak } \\
\text { Langsung M } \\
(\mathbf{p 1 ~ x ~ p 3 ) ~}\end{array}$ & Pengaruh Total \\
\hline $\mathrm{P} 1$ & $\mathrm{X} \rightarrow \mathrm{M}$ & 0,425 & - & 0,425 \\
$\mathrm{P} 2$ & $\mathrm{X} \rightarrow \mathrm{Y}$ & 0,327 & - & 0,327 \\
$\mathrm{P} 3$ & $\mathrm{M} \rightarrow \mathrm{Y}$ & 0,383 & - & 0,383 \\
$\mathrm{P} 4$ & $\mathrm{X} \rightarrow \mathrm{M} \rightarrow \mathrm{Y}$ & 0,425 & 0,162 & 0,587 \\
\hline
\end{tabular}

Sumber: Data diolah, 2017

Berdasarkan hasil rangkuman pada Tabel 3. dapat dijelaskan bahwa brand image $(\mathrm{X})$ terbukti berpengaruh positif dan signifikan terhadap persepsi harga (M), yang ditunjukkan oleh nilai koefisien jalur sebesar 0,425, dengan tingkat signifikansi atau $p$ value $=0,000$, yang berarti sangat signifikan. Koefisien jalur 
bertanda positif, dapat diartikan bahwa meningkatnya brand image yang dimiliki oleh konsumen akan mampu meningkatkan persepsi harga konsumen pada Pie Susu Asli Enaaak di Kota Denpasar, maka hipotesis 1 yang berbunyi, brand image berpengaruh positif dan signifikan terhadap persepsi harga konsumen pada Pie Susu Asli Enaaak di Kota Denpasar terdukung.

Brand image $(\mathrm{X})$ terbukti berpengaruh positif dan signifikan terhadap niat beli konsumen (Y), yang ditunjukkan oleh nilai koefisien jalur sebesar 0,327, dengan tingkat signifikansi atau $p$ value $=0,000$, yang berarti sangat signifikan. Koefisien jalur bertanda positif, dapat diartikan bahwa meningkatnya brand image yang dimiliki oleh konsumen akan mendorong terjadinya niat beli konsumen pada Pie Susu Asli Enaaak di Kota Denpasar, maka hipotesis 2 yang berbunyi, brand image berpengaruh positif dan signifikan terhadap niat beli konsumen pada Pie Susu Asli Enaaak di Kota Denpasar terdukung.

Persepsi harga (M) terbukti berpengaruh positif dan signifikan terhadap niat beli konsumen (Y), yang ditunjukkan oleh nilai koefisien jalur sebesar 0,383, dengan tingkat signifikansi atau $p$ value $=0,003$, yang berarti sangat signifikan. Koefisien jalur bertanda positif, dapat diartikan bahwa meningkatnya persepsi harga yang dimiliki oleh konsumen akan mendorong terjadinya niat beli konsumen pada Pie Susu Asli Enaaak di Kota Denpasar, maka hipotesis 3 yang berbunyi, persepsi harga berpengaruh positif dan signifikan terhadap niat beli konsumen pada Pie Susu Asli Enaaak di Kota Denpasar terdukung.

Persepsi harga (M) memediasi pengaruh positif brand image (X) terhadap niat beli konsumen (Y), yang ditunjukkan oleh nilai koefisien jalur sebesar 0,587, 
dengan tingkat signifikansi atau $p$ value $=0,000$, yang berarti sangat signifikan. Koefisien jalur bertanda positif, dapat diartikan bahwa persepsi harga akan mampu meningkatkan brand image pada diri konsumen sehingga meningkatkan niat beli terhadap Pie Susu Asli Enaaak di Kota Denpasar terdukung, maka hipotesis 4 yang berbunyi, persepsi harga memediasi pengaruh positif brand image terhadap niat beli konsumen pada Pie Susu Asli Enaaak di Kota Denpasar terdukung.

Uji Sobel digunakan untuk menguji signifikansi peran mediasi variabel persepsi harga digunakan rumus Sobel. Berdasarkan diagram jalur pengaruh tidak langsung tersebut, maka dapat dihitung Standar error koefisien a dan b ditulis dengan $\mathrm{S}_{\mathrm{a}}$ dan $\mathrm{S}_{\mathrm{b}}$, besarnya standar error tidak langsung (indirect effect) $\mathrm{S}_{\mathrm{ab}}$ dihitung dengan rumus berikut ini:

$$
S_{\mathrm{ab}}=\sqrt{b^{2} S_{a}^{2}+a^{2} S_{b}^{2}+S_{a}^{2} S_{b}^{2}}
$$

Keterangan :

$\mathrm{S}_{\mathrm{ab}} \quad=$ besarnya standar error tidak langsung

$\mathrm{S}_{\mathrm{a}} \quad=$ standar error koefisien a

$\mathrm{Sb}=$ standar error koefisien $\mathrm{b}$

a $\quad$ jalur $\mathrm{X}$ terhadap $\mathrm{M}$

$\mathrm{b} \quad=$ jalur $\mathrm{M}$ terhadap $\mathrm{Y}$

$$
\begin{aligned}
& S_{a b}=\sqrt{\left(0,648^{2}\right) 0,068^{2}+\left(0,683^{2}\right) 0,065^{2}+(0,065)^{2}(0,068)^{2}} \\
& S_{\mathrm{ab}}=0,044
\end{aligned}
$$

Untuk menguji signifikansi pengaruh tidak langsung maka menghitung nilai $\mathrm{z}$ dari koefisien ab dengan rumus sebagai berikut:

$$
\mathrm{Z}=\frac{a b}{S_{a b}}
$$

Keterangan: 
$\mathrm{S}_{\mathrm{ab}}=$ besarnya standar error tidak langsung

$\mathrm{ab}=$ jalur $\mathrm{X}$ terhadap $\mathrm{M}$ (a) dengan jalur M terhadap $\mathrm{Y}(\mathrm{b})$

$$
\begin{aligned}
& z=\frac{(0,648)(0,683)}{0,044} \\
& z=10,058
\end{aligned}
$$

Hasil perhitungan menunjukan perbandingan nilai z hitung sebesar 10,058> z tabel sebesar 0,96, maka Ho ditolak dan Hi diterima. Artinya persepsi harga memediasi pengaruh brand image terhadap niat beli konsumen pada Pie Susu Asli Enaaak di Kota Denpasar.

Perhitungan pengaruh error (Pei), dapat dilihat dari hasil pengaruh error (Peli) sebesar 0,648 dan pengaruh error $\left(\mathrm{Pe}_{2}\right)$ sebesar 0,683. Hasil koefisien determinasi total adalah sebagai berikut:

$$
\begin{aligned}
\mathrm{R}_{\mathrm{m}}^{2} & =1-\left(\mathrm{Pe}_{1}\right)^{2}\left(\mathrm{Pe}_{2}\right)^{2} \ldots \ldots \ldots \ldots \\
& =1-(0,648)^{2}(0,683)^{2} \\
& =1-(0,419)(0,466) \\
& =1-0,195=0,805
\end{aligned}
$$

Nilai determinasi total sebesar 0,805 mempunyai arti bahwa sebesar 80,5\% variasi niat beli konsumen dipengaruhi oleh variabel persepsi harga dan brand image, sedangkan sisanya sebesar 19,5 persen dijelaskan oleh faktor lain yang tidak dimasukkan ke dalam model.

Hasil analisis data brand image memberikan pengaruh positif terhadap niat beli konsumen, terlihat adanya brand image yang baik di mata konsumen memberikan pengaruh positif terhadap niat beli konsumen pada Pie Susu Asli Enaaak di Kota Denpasar. Oleh karena itu, sikap dan tindakan konsumen terhadap 
suatu merek sangat ditentukan oleh citra merek tersebut untuk meningkatkan niat beli konsumen.

Hasil penelitian ini searah dengan Deviana (2014) menyatakan citra merek atau brand image memiliki pengaruh positif terhadap niat beli konsumen. Penelitian Harmancioglu et al. (2009) membuktikan bahwa brand image memiliki pengaruh positif terhadap keputusan pembelian konsumen. Johan (2010) menyatakan hal yang sama dimana brand image memiliki pengaruh positif terhadap niat beli konsumen. Ayu dan Kerti (2014) menyatakan bagi konsumen brand image memiliki pengaruh positif untuk meningkatkan niat beli. Kambiz and Mohammad (2012) menyatakan bahwa citra merek atau brand image memiliki pengaruh positif terhadap niat beli konsumen.

Hasil analisis data diketahui bahwa brand image terhadap persepsi harga berpengaruh signifikan positif. Hal ini mengandung arti bahwa semakin tinggi brand image seorang konsumen pada Pie Susu Asli Enaaak berakibat positif pada niat konsumen untuk membeli. Harga adalah satu elemen bauran pemasaran yang menghasilkan pendapatan, elemen lain menghasilkan biaya, dengan adanya persepsi harga yang sesuai dengan keinginan konsumen akan memberikan respon positif terhadap citra merek suatu produk.

Hasil penelitian ini didukung oleh penelitian Deviana, 2014) menyatakan citra merek atau brand image memiliki pengaruh positif terhadap persepsi harga konsumen. Penelitian Harmancioglu et al. (2009) membuktikan bahwa brand image memiliki pengaruh positif terhadap persepsi harga konsumen. Johan (2010) menyatakan hal yang sama dimana brand image memiliki pengaruh positif terhadap 
niat beli konsumen. Penelitian Eko dan Budi (2013) menyatakan citra merek memiliki pengaruh positif terhadap persepsi harga konsumen. Kevin (2014) menyebutkan bahwa brand image sebagai salah satu faktor yang mempengaruhi persepsi harga konsumen.

Hasil analisis data diketahui bahwa persepsi harga terhadap niat beli konsumen berpengaruh signifikan positif. Hal ini mengandung arti bahwa semakin baik persepsi harga yang ditetapkan oleh Pie Susu Asli Enaaak berakibat positif pada niat beli konsumen. Konsumen akan mempersepsikan harga, baik itu tinggi atau rendah, akan memiliki pengaruh yang kuat terhadap intensitas pembelian konsumen. Faktor-faktor harga mempengaruhi persepsi harga pelanggan, yang pada gilirannya berkontribusi terhadap intensitas pembelian konsumen.

Hasil penelitian ini didukung oleh penelitian Eko dan Budi (2013) menyatakan persepsi harga memiliki pengaruh positif terhadap keputusan pembelian konsumen. Kevin (2014) menyebutkan bahwa persepsi harga sebagai salah satu faktor yang mempengaruhi niat beli konsumen. Hal yang sama dinyatakan oleh Johan (2010) variabel persepsi harga memiliki pengaruh positif terhadap niat beli konsumen. Kambiz and Mohammad (2012) persepsi harga memiliki pengaruh positif dalam meningkatkan niat beli konsumen. Jamaliah et al. (2013) menyatakan persepsi harga secara positif berpengaruh terhadap niat beli konsumen.

Hasil analisis data diketahui bahwa persepsi harga dapat memediasi pengaruh brand image terhadap niat beli konsumen secara positif. Hal ini mengandung arti bahwa semakin baik persepsi harga yang ditentukan oleh Pie Susu Asli Enaaak akan 
memberikan citra merk atau brand image yang baik di mata konsumen berakibat positif sehingga meningkatkan niat beli konsumen pada Pie Susu Asli Enaaak di Kota Denpasar. Konsumen akan memberikan penilaian yang obyektif terhadap persepsi harga untuk menciptakan citra merek yang positif, baik itu tinggi atau rendah, akan memiliki pengaruh yang kuat terhadap intensitas pembelian konsumen pada Pie Susu Asli Enaaak di Kota Denpasar.

Hasil penelitian ini sesuai dengan penelitian Parisa (2014) menyatakan dalam penelitiannya persepsi harga mampu memediasi pengaruh positif citra merek terhadap niat beli konsumen. Kuang et al. (2011) membuktikan dalam penelitiannya citra merek berpengaruh positif dengan niat beli konsumen melalui mediasi persepsi harga. Yungki (2010) dalam penelitiannya membuktikan persepsi harga mampu memediasi pengaruh positif citra merek terhadap niat beli konsumen. Kevin (2014) menemukan dalam penelitiannya persepsi harga mampu memediasi pengaruh citra merek terhadap niat beli konsumen. Ria dan Gatot (2014) membuktikan terdapat peran mediasi persepsi harga dalam menciptakan pengaruh positif citra merek terhadap niat beli konsumen.

Hasil penelitian ini dapat memberikan masukan untuk Pie Susu Asli Enaaak di Kota Denpasar sebagai produsen harus tetap mempertahankan yang disebut dengan brand image yang dimiliki. Selain untuk menghadapi persaingan, brand image yang dimaksud seperti rasa yang dijaga dengan varian baru serta bahan dasar pembuatan pie susu yang berkualitas dengan ciri khas yang gurih dan enak serta tahan lama untuk dibawa pulang maupun sebagai oleh-oleh. 
Pie Susu Asli Enaaak di Kota Denpasar sebagai produsen untuk peningkatan jumlah konsumen harus memiliki strategi tertentu untuk memenangkan persaingan, persepsi harga merupakan strategi yang baik saat ini untuk diterapkan seperti penetapan harga yang tidak terlalu mahal, harga sesuai dengan rasa pie susu yang dijual kepada konsumen, serta harga mampu bersaing dipasaran sehingga konsumen merasa senang berbelanja untuk membeli dan menikmati Pie Susu Asli Enaaak baik untuk dikonsumsi ataupun sebagai oleh-oleh.

Pie Susu Asli Enaaak di Kota Denpasar sebagai produsen harus tetap mempertahankan citarasa, sajian dan ciri khas dari Pie Susu Asli Enaaak yang memiliki rasa gurih, enak dan tahan lama di mata konsumen sehingga lebih banyak konsumen yang tertarik untuk menikmati Pie Susu Asli Enaaak di Kota Denpasar.

\section{SIMPULAN DAN SARAN}

Simpulan dari hasil pembahasan adalah brand image berpengaruh positif dan signifikan terhadap niat beli konsumen pada Pie Susu Asli Enaaak di Kota Denpasar. Brand image berpengaruh positif dan signifikan terhadap persepsi harga konsumen pada Pie Susu Asli Enaaak di Kota Denpasar. Persepsi harga berpengaruh positif dan signifikan terhadap niat beli konsumen pada Pie Susu Asli Enaaak di Kota Denpasar. Persepsi harga memediasi pengaruh positif brand image terhadap niat beli konsumen pada Pie Susu Asli Enaaak di Kota Denpasar.

Saran-saran yang dapat diberikan sebagai produsen produk Pie Susu Asli Enaaak di Kota Denpasar adalah sebagai produsen produk Pie Susu Asli Enaaak di Kota Denpasar sedapat mungkin menawarkan produk yang sesuai dengan kebutuhan dan keinginan konsumen, sehingga sebagai produsen memiliki brand 
image yang kuat di mata konsumen. Pie Susu Asli Enaaak untuk menjaga brand image yang kuat di mata konsumen dengan tetap mempertahankan kualitas dan kuantitas dari produknya dengan menjaga cita rasa dan meningkatkan hasil produksi sehingga memenuhi kebutuhan konsumen yang berbelanja di Pie Susu Asli Enaaak.

Sebagai produsen produk Pie Susu Asli Enaaak di Kota Denpasar harus mempertahankan persepsi harga yang sudah ditetapkan sehingga memiliki daya saing untuk memenangkan persaingan dalam meningkatkan niat pembelian konsumen. Strategi yang dapat dilakukan untuk mempertahankan persepsi harga yaitu seperti adanya potongan harga bagi konsumen yang berbelanja lebih dari 4 box, adanya layanan antar jemput untuk konsumen yang berbelanja lebih dari 10 box di wilayah Denpasar dan Kuta tanpa dipungut biaya kiriman. Strategi ini akan mampu memenangkan persaingan dalam meningkatkan niat pembelian konsumen dikarenakan konsumen merasa mudah, aman dan cepat apabila berbelanja di Pie Susu Asli Enaaak.

Bagi penelitian selanjutnya diharapkan hasil penelitian ini dapat dipergunakan sebagai referensi dalam menilai niat beli konsumen dan mengukur niat beli konsumen dengan variabel yang lebih up to date seperti trust brand, esteem needs diaplikasikan di tempat lainnya seperti perusahaan BUMN, Hotel dan lainnya.

\section{REFERENSI}

Aaker A. David, (1997). "Manajemen Equitas Merek". Jakarta:Spectrum Mitra Utama 
Agarwal, R dan Sinha, A, P. (2003). Object Oriented Modeling with UML: A Study of Developer's Perceptions. New York: ACM

Andrie Ch. Salhuteru dan Harold Hursepuny, (2013). Analisa Ekuitas Merek terhadap Keputusan Pembelian Sepeda Motor Merek Yamaha di PT Hasjrat Abadi Cabang Ambon. Jurnal Manajemen Ekonomi dan Akuntansi. 2(1): h: $1-122$

Deviana Wijoyo, (2014). Pengaruh Consumer Excitiment, Consumer Esteem dan Impulse Buying Intention Terhadap Impulse Buying Behavior Pada Konsumen Hypermarket Ciputra World Surabaya. Jurnal Manajemen dan Bisnis. 3(1): h: 1-7

Eko Nurdin Kurnianto dan Budi Astuti, (2013). Analisis Pengaruh Komponen Pembentuk Ekuitas Merek terhadap Minat Beli. Jurnal Manajemen Ekonomi Nasional. 4(1): h: 458-466

Jamaliah Mohd. Yusof, Gurmit Kaur Bariam Singh, Rashidah Abdul Razak, (2013). Purchase Intention of Environment-Friendly Automobile. Journal Procedia - Social and Behavioral Sciences 8(5): h: 400 - 410

Joshi Pradeep, (2012). Effect of Environmental Concern and Social Norms on Environmental Friendly Behavioral Intentions. Business Intelligence Journal. 5(1): h: 169-175

Johan wahyudi Amzah, (2010). Pengaruh Gengsi, Kepuasan dan Komunikasi Perusahaan terhadap Woth of Mouth dan Niat Beli Kembali dengan Variabel antara Identifikasi Merk (kasus pada produk Blacberry di Surabaya). Jurnal Ekonomi Erlangga. 3(1): h: 1-128

Julina dan Desrir Miftah, (2014). Perbedaan perspektif konsumen berdasarkan gender terhadap niat beli produk asing. Jurnal Parallela. 1(1): h:1-88

Kambiz Heidarzadeh Hanzaee and Mohammad Javad Taghipourian, (2012). The Effects of Brand Credibility and Prestige on Consumers Purchase Intention in Low and High Product Involvement. Journal Basic. Appl. Sci. Res., 2(2): h: 1281-1291

Kevin Goenawan, (2014). Pengaruh Produk Attributes, Brand Name, Product Price, dan Social Influence terhadap Purchase Intention Android Smartphone di Surabaya. Jurnal Ilmiah Ekonomi. 3(1): h: 1-17

Kuang-peng Hung, Annie Huiling Chen, Norman Peng, Chris Hackley, Rungpaka Amy Tiwsakul, Chun-lun Chou, (2011),"Antecedents of Luxury Brand Purchase Intention". Journal of Product \& Brand Management. 20(6): h: 457-467 
Kuenzel, Sven \& Sue Vaux Halliday. (2008), "Investigating Antecedents and Consequences of Brand Identification". Journal of Product \& Brand Management. 293-304

Kotler, P. dan Keller, K.L.,(2007), "Manajemen Pemasaran", Cet 2, Edisi 12, Jilid 1, Alih bahasa: Benyamin Molan. Penerbit PT INDEKS.

Kotler, Philip and G. Armstrong. (2012). Principles of Marketing. 14th ed. New Jersey: Prentice Hall.

Mangkunegara, A. A. Anwar Prabu. (2011). Manajemen Sumber Daya Manusia Perusahaan. Bandung: PT. Remaja Rosdakarya

Mowen, J. dan Minor, M. (2007). Perilaku Konsumen. Jakarta : Erlangga

Pangastuti Arsinta, Gusti Ayu., Purnami. Ni Made., (2015). Peran persepsi Harga dalam Memediasi Pengaruh Kredibilitas Celebrity Endorser pada Niat Beli Produk Kosmetik Maybelline di Kota Denpasar. Jurnal Manajemen, Strategi Bisnis dan Kewirausahaan. 9(2): h: 123-134

Pavlou, P.A. (2003). "Consumer Acceptance of Electronic Commerce : Integrating Trus and Risk With The Technology Acceptance Model,"International Journal of Technology, 14(1): h: 39-52

Rahmawati Setyaningsih, Suyudi Mangunwihardjo, Harry Soesanto, (2007). Analisis faktor-faktor yang Mempengaruhi Ekuitas Merk untuk Meningkatkan Minat Beli Ulang (Studi kasus pada kedai kopi Dome di Surabaya). Jurnal Studi Manajemen dan Organisasi. 4(2): h: 30-43

Rangkuti, Freddy. (2007). The Power of Brand. Jakarta: PT. Gramedia Pustaka Utama

Ria Darmasari dan Gatot Wijayanto, (2014). Pengaruh Brand Equity dalam membentuk Lifestyle dan Customer Value pada pengguna Merek Smartphone di Kota Pekanbaru. Jurnal Tepak Manajemen Bisnis. 6(2): h: 86-98

Schiffman dan Kanuk. (2010). Perilaku Konsumen. Jakarta: PT. INDEK

Sreejesh, S., (2015). Consumers' Perceived Brand Aspiration and Its Impact on Intention to Pay Price Premium: Moderating Role of Brand Jealousy. Journal Theoretical Economics Letters. 5(1): h: 273-284

Suprapti, Ni Wayan Sri. (2010). Prilaku Konsumen, Pemahaman Dasar dan Aplikasinya Dalam Strategi Pemasaran. Bali : Udayana University Press.

Thiripurasundari, U., and Natarajan, P., (2011). Factors Facilitating Brand Equity Dynamics (A Study on Indian Car Industry). International Refereed Research Journal. 2(2): h: 148-160 
E-Jurnal Manajemen Unud, Vol. 8, No. 3, 2019: 1665 - 1695

Yungki Hary Wibisono, (2010). Faktor-faktor yang Mempengaruhi Perilaku Pembelian dengan Perilaku Niat sebagai Variabel Intervening pada situs kaskus. Artikel ilmiah. 2(5): h:1-8

Zohreh Dehdashti Shahrokh and Arman Deilami Azodi, (2013). The Effect of Country of Origin Image on Brand Equity and Purchase Intention. Journal of Applied Environmental and Biological Sciences. 3(12): h: 52-61 